\title{
Soldiers to Citizens: The Link between Military Service and Volunteering
}

\author{
Rebecca Nesbit \\ University of North Carolina-Charlotte \\ Department of Political Science \\ 440 Fretwell \\ 9201 University City Boulevard \\ Charlotte, North Carolina 28223 \\ Tel: (812) 320-7406 \\ Email: bnesbit@indiana.edu
}

\author{
David A. Reingold \\ Indiana University \\ School of Public and Environmental Affairs \\ 1315 E. $10^{\text {th }}$ Street \\ Bloomington, Indiana 47401 \\ Tel: (812) 855-0635 \\ Fax: (812) 855-7802 \\ Email: reingold@indiana.edu
}

This research was supported by grants from the Carnegie Corporation of New York and the Center on Philanthropy at Indiana University. The authors gratefully acknowledge their support for this research. 


\begin{abstract}
Research has shown that military service is linked with some forms of political engagement, such as voting, especially for minorities. In this paper, we explore the relationship between military service and another measure of civic engagementvolunteering. Military service can help to overcome barriers to volunteering by helping to socialize people with a norm of civic responsibility, by providing social resources and skills that compensate for the lack of personal resources, and by making people aware of opportunities to volunteer and "asking" them to do so. The data used to explore this research question are from the Census Bureau's Current Population Survey (CPS) 2005 September supplement on volunteering. We find that military service is positively related to volunteering among blacks and Hispanics. Married veterans and veterans over the age of 65 are more likely to volunteer than nonveterans.
\end{abstract}

\title{
Keywords
}

Volunteering, civic engagement, military service, veterans 


\section{Introduction}

In this paper, we view the military as a government institution with implications for civil society. The military, just like any other institution, has its own set of norms and rules, and new recruits to the military are socialized with the values of the military, such as duty, honor, loyalty to country, and other values that support a democratic society (Lovell \& Stiehm, 1989). Research has found a link between military service and some political behaviors, like voting or working on a political campaign (Ellison, 1992; M. Kent Jennings \& Gregory B. Markus, 1977; Leal, 1999; Teigen, 2006), which seems to indicate that military socialization creates more active citizens. It is possible, then, that military service is related to other measures of good citizenship behavior beyond political participation. This paper seeks to investigate the impact of military service on volunteering, another important measure of civic engagement. The data used to explore this research question are from the Census Bureau's Current Population Survey (CPS) 2005 September supplement on volunteering.

We begin by investigating the military as an institution and the empirical evidence for how military service influences civic and political attitudes and behaviors. Next, we outline theoretical reasons why military service can influence individuals' volunteering behaviors. In the third section of the paper, we present our hypotheses related to military service and volunteering. Finally, we provide an overview of the data and methods, followed by a discussion of the results of the analysis.

\section{The Military as an Institution of Civic Engagement}


Institutions are the "humanly designed constraints", or rules, that "structure incentives in human exchange" and shape human interaction, thereby regulating and increasing the predictability of human behavior (North, 1990: 3; Ostrom, Gibson, Shivakumar, \& Andersson, 2002). In an institution, the collection of formal rules and informal constraints and the process by which they are enforced determine a person's potential actions (North, 1990). These norms and rules determine not only the actions that an individual can do, but also the actions that an individual must or must not do (Crawford \& Ostrom, 1993). Institutions therefore structure the incentives involved in making certain decisions by rewarding and punishing various actions.

Military organizations possess their own unique set of governing rules and norms. The military immediately immerses new recruits in an extensive training program that not only teaches recruits new skills but also continually exposes them to and surrounds them with military values and norms. New cadets in military training institutes immediately undergo a process in which their civilian status is broken down and deconstructed and a new identity is "rebuilt" by constant exposure to military norms, discipline, values and authority (Soeters, Winslow, \& Weibull, 2003). Successful military socialization includes embracing military values, like a sense of pride at being a military member and a sense of loyalty to the military and its traditions (Lovell \& Stiehm, 1989).

Not only is the military an institution according to the definition given above, but the military is an especially demanding institution. The military fits Goffman's (1959) definition of a "total institution," meaning that it is a place where a large number of individuals in a similar situation are separated from the larger society and are subject to formally administered rules that govern all aspects of daily life. Others call the military a 
"greedy institution" because of the many heavy demands it makes upon members, such as being on a permanent on-call basis while on duty, being required to relocate on short notice, and having many aspects of daily life dictated by the institution (Soeters et al., 2003). After educational institutions, the military is the governmental institution that more American men commonly experience (Teigen, 2006), so not only is the military a demanding institution, but it is an institution that affects great numbers of people. Data from the 2000 Census estimate that 12.7 percent of the U.S. adult population were veterans; this represents approximately 26.4 million people (Richardson and Waldrop, 2003). Because so many individuals spend some amount of time serving in the military, researchers of civic engagement need to understand the impact of military service on the post-military civic behaviors of participants. Participation in other institutions, such as families, schools and voluntary associations, often leads to greater civic engagement (Flanagan, Bowes, Jonsson, Csapo, \& Sheblanova, 1998; Youniss et al., 2002), so it is feasible that a "total" governmental institution like the military will impact civic behavior as well.

\section{How Military Service Impacts Political Attitudes and Behaviors}

Military service impacts people's attitudes and abilities, and these increased capacities and improved attitudes are supposed to carry over into civilian life after a person leaves military service, creating the perception that veterans are more patriotic and more prepared and willing to serve the county (President's Commission on an AllVolunteer Armed Force, 1970). Most Americans view military members as men and women who are willing to set aside their own self-interest to follow the path of duty and 
honor in serving their country (Charles C. Moskos, 2000). Empirical researchers have sought to determine whether this conventional wisdom holds up — does military service impact veterans' civic attitudes and behaviors after military service is concluded?

Overall, empirical evidence indicates that military service has, at best, only a small positive impact on political and civic attitudes compared to political and civic behaviors. Jennings and Markus (1977) investigated the impact of Vietnam War military service on veterans' political attitudes and values, and they found that military service modestly reduced political cynicism and trust and slightly increased interest in and attention to world affairs. Another study of Vietnam veterans' attitudes found that most veterans registered ambivalence about politics, political parties and voting, but combat veterans exhibited alienation toward politics and the political system (Pollack, White, \& Gold, 1975). Schrieber (1979) looked at the impact of military service in WWII and the Vietnam War on attitudes toward the military, the government, international affairs, authoritarianism, and violence, and he found no significant opinion differences between veterans and nonveterans except in their feelings toward the military. Others have also demonstrated that most veterans experience few lasting changes in their values and beliefs, with little or no change in values and beliefs for those who served shorter periods of time in the military (Lovell \& Stiehm, 1989). The empirical evidence is not conclusive enough to paint a strong picture regarding the relationship between military service and political attitudes upon return to civilian life, but most of the evidence indicates little association between military service and people's political and civic attitudes. 
Although military service does not appear to produce lasting positive impacts on veterans' political or civic attitudes, military service does not lead to more authoritarian and anti-democratic attitudes either. Some researchers fear that military service negatively impacts civic behaviors because of the military's strict adherence to authoritarian governance and rules. They argue that because the military is hierarchical and authoritarian, it will not instill a participatory ethic in military members and will instead lead to more authoritarian values and actions (Gorham, 1992) — values that are not supportive of democracy and can discourage good civic behaviors. However, empirical evidence shows that veterans are not more authoritarian, intolerant, and violence-accepting than nonveterans, including Vietnam War veterans (M. Kent Jennings \& Gregory B. Markus, 1977; Schreiber, 1979).

Although military service does not seem to change veterans' attitudes, research indicates that military service does impact civic and political behaviors. In particular, military service is associated with more active forms of political participation rather than passive participation (Jennings \& Markus, 1976). Ellison (1992) found that black veterans were not more likely than non-veterans to participate in low-initiative political activities, such as voting in national or local elections, but they were more likely to engage in high-initiative political activities, such as contacting political officials or working on a political campaign. For Latinos, however, participation in the military does seem to increase voting turnout and participation in low-intensity political activities, such as wearing a political button, donating to a political campaign or signing a petition (Leal, 1999). Indeed, military service is associated with higher voting turnout rates in general, except among veterans of the Vietnam War era (Teigen, 2006). However, not all studies 
of the impact of military service on political participation find positive effects. For instance, Franzich (1982) found that graduates of military academies were less likely to vote than civilians. In general, however, the preponderance of the evidence indicates that military service is associated with greater political participation.

To summarize, military service has little effect on civic and political attitudes, but military service is related to some forms of political participation, such as voting, especially among minority populations. Political attitudes and behaviors, however, are not the only measures of civic engagement. Researchers have yet to investigate any linkage between volunteering and military service, even though volunteering serves as another important aspect of civic engagement. If military service is associated with increased political participation and voting, the military service might also be linked to increased volunteering.

\section{How Military Service Can Impact Volunteering}

Institutions determine the incentives for doing or not doing various actions, and the military, just like other institutions, can impact the incentives for individuals to volunteer. As a springboard for exploring how military service can affect volunteering, we begin by introducing the reasons why people do not volunteer: people do not volunteer because they cannot, because they do not want to, or because no one has asked them to volunteer (Brady, Verba, \& Scholozman, 1995). Volunteers can lack the necessary resources for volunteering, the motivation to volunteer, or perhaps a window of opportunity that would allow volunteering. Socialization through military service can 
provide individuals with the means to overcome each of these three barriers to volunteering.

Providing Skills and Resources for Volunteering. Volunteering takes resources, such as time, money and participatory skills; those individuals without these resources are unable to volunteer. People in higher socioeconomic groups have higher incomes and educations and thus possess more resources, so these individuals tend to volunteer more (Boraas, 2003; Hayghe, 1991). Acquisition of resources for volunteering requires human and social capital. Social status variables, such as age, race, and gender indirectly affect volunteering because they determine how much human, social and cultural capital people accumulate and can use for volunteer work (Wilson \& Musick, 1997). Institutions can moderate the relationship between social status variables and participation. For instance, researchers have demonstrated that religious participation moderates the relationship between race and volunteering. In general, blacks are less likely to volunteer than whites (Boraas, 2003; Hayghe, 1991). However, Musick, Wilson and Bynum found that while blacks possess less human capital than whites due to socioeconomic variables, they have more social and cultural capital than whites because of their more frequent religious participation (Musick, Wilson, \& Bynum, 2000). Participation in religious organizations offers the disadvantaged an opportunity to develop skills relevant to civic participation and volunteering which helps people to overcome the barriers to volunteering (Verba, Scholozman, \& Brady, 1995). Thus institutions can provide compensatory social resources that lead to greater volunteering. 
Just like religious organizations, the military also provides a venue for developing the skills and acquiring the resources necessary for volunteering, especially for people from lower socioeconomic classes. The military offers opportunities for education and training so people can develop their communication and organizational skills. Because the military is a large bureaucracy, it also allows people to learn the skills necessary to function successfully in an organization. In addition, individuals serving in the military interact daily with people from different racial, geographic, socioeconomic, and religious backgrounds, and yet they must all strive toward a common goal. By integrating diverse individuals into a common social experience and network, military service teaches the necessity of working with others and the skills to do so (M. Kent Jennings \& Gregory B. Markus, 1977). In fact, many attribute the success of military units to the cohesion and teamwork that develops within the unit, especially during situations of stress (Ambrose, 1997). Finally, military service also affords people the opportunity to lead groups, and this fosters leadership skills that can be applied in a range of settings. In all these ways, military service can provide individuals with the resources and skills that open up the pathways to voluntarism.

Motivating People to Volunteer. According to Brady, Verba, and Schlozman, the second reason that people don't volunteer is because they don't want to. This means that a person with the requisite resources for volunteering might still lack the motivation to volunteer. Volunteers are often motivated by the need to satisfy their personal and social goals (Cnaan \& Goldberg-Glen, 1991), although the motivating values and goals can be different from person to person (Clary \& Snyder, 1999). Meaning is a social construct, 
and an individual's perceptions about the self, social action, and personal responsibility are conditioned by institutional forces (DiMaggio \& Powell, 1991). Institutions can influence and determine what actions an individual considers necessary or important. Thus, to a certain extent institutions can shape the goals and values that contribute to volunteering behaviors.

For most participants, military service occurs between the ages of 18 and 26, although during WWII the age range went up to the mid-30's (Schreiber, 1979). Thus, most military recruits are transitioning from adolescence to adulthood. Adolescence is a crucial time in people's lives when they are forming their own social, political and civic identities in the world (Damon, 2001). These identities are critical because they lead to adult attitudes and behaviors. For instance, a person's political socialization during youth is directly linked to his or her subsequent adult behaviors and attitudes (Beck \& Jennings, 1982). As people move into young adulthood, their identities are still malleable. Young adulthood is a transition from adolescence to the adult world, and for young adults entering the military, their military experience can potentially have a large impact on their identity development and value systems.

Part of the transition to adulthood is receiving all the requisite rights and responsibilities of citizenship. The term "citizen-soldier" was born from this idea: that the military both teaches and bestows citizenship (Cohen, 1985). Although some militaries throughout the world have overt political goals and seek to directly teach citizenship (Wakenhut, 1979), other militaries only seek to transmit the norms and values of the institution, which are more indirectly related to citizenship. No matter the process by which they are installed, all militaries seek to cultivate an environment where 
members are subject to military authority and subscribe to military goals and values, which center on loyalty and duty to country. The feeling of the necessity of serving one's country is generally believed to be supportive of democracy. Value transmission begins during the initial stages of military membership when recruits undergo a process whereby their normal civilian status is broken down and replaced with a new identity as a member of the military (Soeters et al., 2003). Successful military socialization leaves military recruits with the values of duty, honor, and loyalty to the country (Lovell \& Stiehm, 1989). Values such as these are supportive of general democratic values and feelings. After returning to civilian life, veterans can act upon these values, such as loyalty to country, by volunteering.

Providing Opportunities to Be Asked to Volunteer. The final reason that people may not volunteer is because they were not asked to volunteer. This implies that people might be unaware of volunteer opportunities and need a friend or family member to point these opportunities out to them. Empirical research has shown that people are four times as likely to volunteer when they are asked to do so (Wymer, 1997). One reason why being asked to volunteer is important is that for some people the social benefits of volunteering are most salient (Chinman \& Wandersman, 1999). People will be more likely to volunteer when others that they know volunteer or when they have the opportunity to volunteer with a friend or relative.

One of the primary ways that military service can provide more opportunities to volunteer or opportunities for people to be asked to volunteer is through veterans associations. Veterans associations provide many opportunities for members to both 
socialize and to give their time toward group endeavors. At the end of WWII, a survey of veterans about to be discharged indicated that they intended to be active in veterans and other civic organizations after the war (Stouffer, 1949). Many veterans associations also make great efforts to include as many survivors as possible in their organizations (Mettler, 2002). Historically, military veterans have been heavily involved not only in veterans associations, but other types of associations, such as fraternal organizations (Skocpol, 1999). In fact, in the aftermath of every war (except the Vietnam War) there was an increase in fraternal organization memberships (Skocpol, 1999). Although participation in many types of organizations has decreased over the past couple decades, participation in veterans organizations has increased during the time period from 1974 to 1994 (Rotolo, 1999). The number of independent veterans associations almost tripled during the years 1980 and 1997, although membership in individual organizations declined somewhat (Putnam, 2000). Therefore, it is likely that large numbers of veterans participate in veterans associations or fraternal organizations, and membership in voluntary associations is strongly linked with volunteering (Hodgkinson, Nelson, \& Sivak, 2002). Most volunteers are found through networks of religious and associational memberships (Putnam, 2000). Thus, if veterans are more likely to join veterans and civic associations, they will also be more likely to volunteer.

In summary, military service can lead to more volunteering by helping to socialize people with a norm of civic responsibility, by providing social resources and skills that compensate for the lack of personal resources, and by making people aware of opportunities to volunteer and "asking" them to do so. However, we have also discussed 
how some researchers feel that military service could potentially decrease volunteering because of its authoritarian and hierarchical structure. Therefore, we develop specific hypotheses for the instances when we would expect military service to be positively related to volunteering.

\section{Hypotheses}

In this paper, we have discussed several reasons why military service might lead to increased volunteering. We have also presented reasons why military service might lead to decreased civic engagement, i.e. because of the authoritarian and hierarchical nature of the military. Given these arguments, it is difficult to cast one general hypothesis about the nature of the relationship between military service and volunteering. Therefore, we will create more specific hypotheses about the specific groups in the military for whom we expect a positive relationship between their military service and their volunteering.

First, we expect that the relationship between military service and volunteering will be different for different racial groups. The military is seen a more level playing field for those of different races. In particular, the military can function much like churches do in fostering civic engagement. The military provides disadvantaged youth with the opportunity to learn occupational and social skills that are helpful, and often necessary, in volunteering. Military service teaches people how to cooperate with people different than them, how to work within a large bureaucracy, and the necessity of responding to authority (Binkin, Eitelberg, Schexnider, \& Smith, 1982; Charles C. Moskos \& Butler, 1996). By learning these skills, minorities who have served in the 
military can obtain much better educational and occupational outcomes after their service than their nonveteran counterparts (Butler, 1991). And along with being in higher-status jobs, black military veterans receive higher wages than nonveterans (Angrist, 1993; Mare \& Winship, 1984; Xie, 1992). In this way, the military can serve as a vehicle for social mobility for minorities. And given the strong connections between income, class and volunteering (McPherson, 1981; Wilson \& Musick, 1997), it is reasonable to expect that as blacks move upward socially and economically that they will be more civically engaged, including volunteering. We believe that this same process will work for Hispanics as well as blacks. This brings us to our first hypotheses:

H1A: Blacks who served in the military will be more likely than nonblacks who served in the military to volunteer after military service is completed.

H1B: Hispanics who served in the military will be more likely than non-Hispanics who served in the military to volunteer after military service is completed.

We also expect to see some differences between married and nonmarried veterans in terms of their civic engagement after leaving the military. One reason for this is that married veterans have more social support at home to help them through the period of readjustment to civilian life and to help with recovery from service-related trauma. One study of stress-related disorders in veterans and nonveterans of the Vietnam era found that four out of the five stress-related disorders studied-post-traumatic stress, anxiety, depression and alcohol abuse-were associated with lower levels of social support (Boscarino, 1995). One of the risk factors for suicide among veterans is a lack of social 
support, including not being married (Lambert \& Fowler, 1997). Other studies confirm these findings - having a stable marriage contributes to a beneficial social network that helps individuals to work through the problems confronting them. Marriage can be a particularly important relationship in helping veterans to successfully cope with the stress of stress of military service as they return to civilian life (Laufer \& Gallops, 1985; Shehan, 1987). It is reasonable to expect, therefore, that married veterans will more easily make the adjustment back to civilian life and will have more of the social stability that is necessary to support volunteering. This forms the basis for our second hypothesis:

$\mathrm{H} 2$ : Married veterans are more likely to volunteer after military service than nonveterans - both married and unmarried.

In the United States over the past century, veterans who served in the military during different periods of service might have had very different experiences which could mediate the influence of military service on subsequent participation and volunteering. Serving in different periods might affect veterans differently because of complicating factors such as the intensity of the conflict or the amount of political support for the military at that particular time or during that particular war.

Veterans who served in the military during different periods of service might experience the military institutions differently from each other. Soeters, Winslow and Weibull (2003) describe military culture as actually being composed of two different subcultures - one "hot" and one "cold." Most of the time, the military falls under the cold organization rubric - when there is no crisis or immediate needs and business 
proceeds as usual. In this stage, the military is characterized as a normal bureaucratic organization. The hot military culture occurs during situations of crisis, such as times of war, and this subculture is characterized more by flexibility and self-management. Empirical research has also found that combat experience can mediate the relationship between military service and participation. For instance, combat and noncombat veterans have very different experiences when readjusting back to civilian life (Pollack et al., 1975). Ellison (1992) also found that combat experience accentuated the relationship between military service and political participation among blacks. Part of the reason that combat veterans act differently than noncombat veterans is because they often experience different military cultures during their service. For soldiers that serve in combat, military service has greater intensity and salience than for those who only served during a period of peace or who did not serve in combat, and intensity and salience of institutional involvement impact how a person experiences an institution and the potential lasting effects of that institution on the person (M. K. Jennings \& G. B. Markus, 1977). Because the culture of the military is more intense during a time of war, especially for those that serve in combat, it is reasonable to expect that military service during these periods will have a greater lasting impact on individuals. Therefore, our third hypothesis regarding military service and volunteering is:

H3: Veterans who served during war will be more likely to volunteer than veterans who served during peacetime.

\section{Data and Methods}




\section{Data and Sample}

The data used to test these hypotheses come from the 2005 September Volunteering Supplement of the Current Population Survey (CPS) ${ }^{1}$. The CPS is a monthly Census Bureau survey conducted on approximately 50,000 households including over 150,000 individuals; it collects information about each household member's labor force participation, demographic characteristics and supplementary topics. Since 2002, the CPS September supplement has collected information about the incidence and intensity of an individual's formal volunteering, as well as information about how, why and where the person volunteers. In the 2005 September supplement, 89,709 respondents were asked both the volunteering questions and the military service questions. For some of the analyses in this paper, the sample size is lower than 89,709 because of missing data on other variables or restrictions in the subgroups to which the analysis is applied. The sample size for each part of the analysis is noted in the tables.

\section{Variables}

Dependent Variables. This paper uses two dependent variables. The first dependent variable is a binary variable representing whether or not the person volunteered in the previous year. This variable is based on two CPS survey questions.

\footnotetext{
${ }^{1}$ We also attempted to replicate this analysis using the Philanthropy Module of the Panel Study of Income Dynamics (COPPS) data. However, we chose not to present these results because (a) the sample size of the COPPS was not sufficiently large to allow for the depth of subgroup analysis that we conducted in this analysis and (b) the military service variables in the COPPS data were only current up to 1994 for household heads and 1985 for household wives so the full span of military periods were not represented in these data. However, when the models are run using the COPPS data to the extent possible with the data, most of the military service variables were not statistically significant. Serving in a period of war was negatively related to volunteering $(\mathrm{p}<.10)$ and being a veteran with a disability was positively related to volunteering $(\mathrm{p}<.10)$.
} 
The first question asks, "Since September $1_{\text {st }}$ of last year, have you done any volunteer activities through or for an organization?" The second question is an additional volunteering memory prompt asked of all respondents who answered "no" to the first question. This prompt says, “Sometimes people don't think of activities they do infrequently or activities they do for children's schools or youth organizations as volunteer activities. Since September $1_{\text {st }}$ of last year, have you done any of these types of volunteer activities?" If the respondent answered yes to either of these questions, then he or she was coded as a volunteer.

The second dependent variable is the log of the number of hours the person volunteered in the last year. In the CPS dataset, this variable represents the number of hours volunteered during the last year for all the organizations the person volunteered for. This variable only contains responses from those respondents who indicated that they volunteered last year, all others were coded as blank. We used the log of hours volunteered to increase normality in the hours volunteered variable. After taking the log of the hours volunteering last year, we coded all those who indicated that they didn't volunteer last year or that volunteered 0 hours as 0 on log of hours volunteered variable. Those who weren't asked the volunteering questions were left as blank/missing on this variable.

Independent Variables. The independent variables for this analysis are grouped into several categories - individual characteristics, household characteristics, military service variables, geographical variables and methodological variables. The analysis contains a variable representing the respondent's age. The individual characteristics section also includes three race dummy variables for whether or not the respondent is 
white (coded as 1), black (coded as 1), or Hispanic (coded as 1). The excluded race category would be all other races, such as Asians or Native Americans. There are also dummy variable representing whether the person is male (coded as 1) or employed (coded as 1). The person's highest grade of school completed is also included in the regression. In the CPS questionnaire, respondents were asked, "What is the highest level of school you have completed or degree you have received?" The answers to this question were placed in various educational categories, such as $9^{\text {th }}$ grade, $10^{\text {th }}$ grade, associate's degree, etc. To create the years of school variable, we recoded each of these categories in terms of the average number of years in school each level of school represents. For instance, a person in the $9^{\text {th }}$ grade was coded as being in school for nine years. The final individual characteristic included in the analysis is a dummy variable that represents whether the person has a disability that might impact their employment. In the CPS data, this question is asked as "Last month you were reported to have a disability. Does your disability continue to prevent you from doing any kind of work for the next 6 months?" If a person answered yes to these questions, then they were coded as having a disability.

The first variable under household characteristics is the log of family income. In the CPS data, family income is coded in a series of comparable categories. For each respondent, we recoded family income to represent the midpoint of the income category represented. The highest income category, $\$ 150,000$ and above, was coded at $\$ 150,000$ because the midpoint of this income category is unknown. We then took the log of these family income recodes. The second variable is the number household earners, which is the number of people in the household who are employed and contribute to the family 
income. We include both of these variables because when controlling for family income, families with more earners are poorer, and poorer families tend to volunteer less often than wealthier families (Freeman, 1997).

The regressions also include two measurements of the presence of children in the household. The first is the number of the respondent's own children under the age of 18 living in the home. The second is a dummy variable which is coded 1 if there are preschool children (0-5 years old) in the family and coded 0 otherwise. The presence of children can constrain the amount of time available for volunteering, but children can also lead to more volunteering, especially through youth-centered activities. The presence of school-aged children in the home has a positive effect on the mother's volunteering (Rotolo \& Wilson, 2006) because the mother often volunteers for organizations that her children are involved in or benefit from, such as schools. The presence of preschool children, however, can decrease the mother's volunteering or hours volunteered because preschoolers require more time and attention than older children and thus constrain the mother's ability to leave the home to go volunteer.

We also control for the volunteering of other members of the household. To this end, we include a variable representing the number of household members, excluding the respondent, who indicated that they that volunteered last year. To control for those who might be in a household by themselves, we also include a dummy variable that is coded 1 if the person lives alone. The final household volunteering variable is the number of people in the household that have never volunteered. In the CPS supplement, respondents who indicated that they did not volunteer last year were asked if they have ever volunteered at any time previously. Those who answered no to this question were 
coded as never having volunteered, and we summed up the number of these individuals in each household to get the number of people in the household who have never volunteered. The correlation between the number of people in the household who volunteered last year and the number of people who have never volunteered is -.18.

Additionally, the regressions also contain several institutional variables that relate to military service. The first is a dummy variable indicating whether or not the person is a veteran. The CPS asks respondents, "Did you ever serve on active duty in the U.S. armed forces?" If the respondents answered yes to this question, then we coded them as being a veteran.

The analysis also contains several military service interaction terms. The first interaction term is being over the age of 65 and a veteran. The over 65 age group are those who served in World War II and who are part of Putnam's long civic generation. We expect this generation to be highly engaged civically, so it is likely that if there is a link between military service and civic engagement, it will be stronger for this particular generation because of their unique experiences. The second interaction term is an interaction between being disabled and being a veteran. Although the disability question does not specifically relate to veterans who might have been disabled in the line of duty, this interaction term can serve as a proxy for disabled veterans. Because a disability can be a barrier to volunteering, it is likely that disabled veterans will be less civically engaged than other veterans. The third interaction term is an interaction between being married and being a veteran. The regressions also contain two interaction terms for race - the interaction of being black and being a veteran and the interaction of being Hispanic and being a veteran. Previous research has shown that military service has a 
greater impact on the future political behaviors of black and Hispanics than on whites or other races. These two interaction terms are intended to capture this effect.

Finally, the regressions also include a dummy variables representing whether the veteran served during a period of war versus a period of peace. In the CPS data, those who have served in the military are asked to indicate the period(s) of service that they served in according to nine different categories-(1) September 2001 or later, (2) August 1990 to August 2001, (3) May 1975 to July 1990, (4) Vietnam War (August 1964 to April 1975), (5) February 1955 to July 1964, (6) Korean War (July 1950 to January 1955), (7) January 1947 to June 1950, (8) World War II (December 1941 to December 1946) and (9) November 1941 or earlier. The war dummy variable was coded as 1 if the respondent indicated that he or she served during either World War I, World War II, the Vietnam War, the Korean War, or August 1990 to August 2001 (Gulf War period).

The regressions also include a few geographical variables. The first is a dummy variable representing whether or not the person resides in a consolidated statistical metropolitan area. The regressions also include three regional dummy variablesnortheast, midwest and south (with west as the excluded base category) as additional controls, although the results for these three variables are not included in the tables. Finally, the regressions also contain a dummy variable for whether the respondent's answers were given by proxy.

\section{Methods}

We employ a different method for each of the two different dependent variables. The first dependent variable, whether the person volunteered last year, is a binary 
variable, so ordinary least squares regression would not be appropriate. Logit regression is more appropriate in this case (Long, 1997). The second dependent variable is the log of hours volunteered last year. This variable is censored at zero, so tobit regression is more fitting for this type of variable (Long, 1997).

\section{Results}

The demographic characteristics of respondents are shown in Table 1. These characteristics are broken down by veteran and volunteer status.

\section{Insert Table 1 about here}

As seen in Table 1, veterans are more likely to be male, white, and older than nonveterans. Veterans are less likely to be employed than nonveterans, most likely because the average age of veterans in the mid- to high 50s, so a considerable number of veterans could be retired. Veterans are also slightly more likely to report a disability (although this disability is not necessarily related to their military service). Volunteersboth veteran and nonveteran - tend to be female, white, and employed. They are also less likely to report a disability. The household structure of volunteers is also that they are more likely to be married and to have children, to live with others who volunteer and to not live alone. In general, veterans report having fewer children and a smaller percentage of preschoolers in the home, which is probably due to the older age of veterans in general.

Table 2 presents the multivariate results for both dependent variables. The first column shows the logit regression coefficients for the dependent variable indicating 
whether the person volunteered during the previous year. The second column of Table 2 shows the tobit regression coefficients for the hours volunteered in the previous year.

\section{Insert Table 2 about here}

Table 2 substantiates the relationships between many of the common individual and household characteristics and volunteering that have been found in previous research. Volunteers are more likely to be female, white, have higher education, be married, have children, and live with others who volunteer or live alone. Volunteering is negatively related to having a disability, having preschool children in the home, and living in a metropolitan area.

The findings regarding the relationship between military service and volunteering are quite interesting. The data show that, overall, being a veteran is negatively related to volunteering, but that for specific groups of people the experience of serving in the military is associated with greater volunteering. All three of our research hypotheses are supported by the data. In support of Hypotheses $1 \mathrm{~A}$ and $1 \mathrm{~B}$, we see that both black and Hispanic veterans are more likely to volunteer and to volunteer more hours than veterans of races and nonveterans. Hypotheses 2 conjectured that married veterans will volunteer more, and this hypothesis was also supported. Finally, Hypothesis 3 claimed that veterans who served during a war period will be more likely to volunteer, and this interaction terms was also positively related to volunteering and hours volunteered.

\section{Discussion}

We find that the relationship between military service and civic engagement is complex. Military service is positively related to volunteering for certain groups of 
people who have served in the military, but not for all veterans overall. Military service is most likely to positively impact the volunteering of people over the age of 65 , married veterans, veterans who are black or Hispanic and those who served in the military during a time of war. These groups of veterans are more likely to have volunteered last year than other veterans and nonveterans, and they volunteer more hours as well.

The finding that black and Hispanic veterans are more likely to volunteer than other veterans fits perfectly with Leal's (1999) and Ellison's (1992) findings that black and Hispanic veterans have higher levels of different types of political activity after leaving military service than white veterans do. This lends support to the idea that the military can serve as a social mobility mechanism for people from lower socioeconomic classes (Charles C. Moskos \& Butler, 1996). The practical and social skills that people learn in the military can be translated to higher status jobs with larger wages (Angrist, 1993; Mare \& Winship, 1984; Xie, 1992), but also perhaps to more civic and political engagement.

We also found that being a married veteran was positively linked to both volunteering and the hours volunteered during the previous year. This lends support to the idea that veterans with a strong, supportive social network can more successfully navigate the transition from military service to civilian life.

Veterans over the age of 65 are more likely to volunteer than veterans in the younger age categories. Veterans in this age category are the cadre of veterans who served in World War II and, in many instances, the Korean War as well. This cohort is particularly known for their high levels of civic and political engagement after leaving military service, partly because their experiences during WWII heightened their desire to 
be involved in their communities upon returning (Brokaw, 1998). Many of these veterans also received benefits through the GI Bill that further impacted their desires to give back to their communities (Mettler, 2005). We would expect this generation to be engaged through volunteering as well. However, given the strong impact of military service upon the civic and political engagement of this cohort, why doesn't military service in later periods have the same impact on veterans? One possible explanation is the changes in the military that have taken place during this century, especially in the move from a military force composed of both volunteers and conscripts to an allvolunteer military force in 1973 . This move has changed both the demographic composition and culture of the military. The military is currently far much less representative of the eligible population than it was previously with the middle class largely being unrepresented in the military (Charles C. Moskos, 1982). The shift to an all-volunteer force has changed the culture of the military as well. Motivations to join the military have shifted more toward occupational incentives for joining the military, such as pay and educational opportunities, rather than feelings of duty and love of country (Laurence, 2006). It is possible that these changes and other differences in the contemporary military are mediating the relationship between military service and volunteering.

This paper shows a relationship between military service of certain demographic groups and volunteering, but other than knowing whether a person is a veteran and when he served we have no data about the length and intensity of military service or other details about the way the respondents experienced the military as an institution. Previous research has shown that many of these variables are potentially important when 
investigating the link between military service and civic attitudes and behaviors. For instance, the branch of the military that a person serves in could make a difference. Franzich (1982) found that members of the Navy and Air Force were more participatory than members of the Army, and members of the Army were more participatory than members of the Marines. We have also noted in this paper the importance of serving in combat as well (Ellison, 1992; Pollack et al., 1975). Some other factors that might impact the relationships between military service and volunteering are the length of military service, the recency of the experience, the intensity of involvement, the way people view the military, and the salience of the military experience (M. Kent Jennings \& Gregory B. Markus, 1977). Future research can do more to illuminate the linkage between military service and volunteering by exploring the impact of some of these additional variables.

\section{Conclusion}

This paper investigated the impact of the military as an institution upon veteran volunteering behaviors after returning to civilian life. Previous research has shown that military service is linked to some forms of political participation, such as voting. We find that military service is also positively related to another measure of civic engagement—volunteering. The relationship between military service and volunteering is complex, however. Black and Hispanic veterans are more likely to volunteer than both their nonveteran counterparts and than white veterans. Married veterans are also more likely to volunteer than single veterans. Finally, veterans over the age of 65 are more likely to volunteer upon leaving the service than veterans from younger age groups. This 
provides evidence that experiencing the military institution, at least for some groups of people, leads to greater civic engagement. 


\section{References}

Ambrose, S. E. (1997). Citizen Soldiers. New York: Simon and Schuster.

Angrist, J. D. (1993). The Effect of Veterans Benefits on Education and Earnings. Industrial and Labor Relations Review, 46(4), 637-652

Beck, P. A., \& Jennings, M. K. (1982). Pathways to Participation. The American Political Science Review, 76(1), 94-108.

Binkin, M., Eitelberg, M. J., Schexnider, A. J., \& Smith, M. M. (1982). Blacks and the Military Washington, DC: Brookings Institution.

Boraas, S. (2003). Volunteerism in the United States. Monthly Labor Review, 3-11.

Boscarino, J. A. (1995). Post-Traumatic Stress and Associated among Vietnam Veterans: The Significance of Combat Experience and Social Support Journal of Traumatic Stress, 8(2), 317-336.

Brady, H. E., Verba, S., \& Scholozman, K. L. (1995). Beyond SES: A Resource Model of Political Participation. American Political Science Review, 89, 271-292.

Brokaw, T. (1998). The Greatest Generation. New York: Random House.

Butler, J. S. (1991). The Military as a Vehicle for Social Integration: The Afro-American Experience as Data. In H. Dietz, J. Elkin \& M. Roumani (Eds.), Ethnicity, Integration, and the Military (Vol. 3, pp. 27-50). Boulder, CO: Westview Press.

Chinman, M. J., \& Wandersman, A. (1999). The Benefits and Costs of Volunteering in Community Organizations: Review and Practical Implications. Nonprofit and Voluntary Sector Quarterly, 28(1), 46-64. 
Clary, E. G., \& Snyder, M. (1999). The Motivations to Volunteer: Theoretical and Practical Considerations. Current Directions in Psychological Science, 8(5), 156159.

Cnaan, R. A., \& Goldberg-Glen, R. S. (1991). Measuring Motivation to Volunteer in Human Services. Journal of Applied Behavioral Sciences 27, 269-285.

Cohen, E. A. (1985). Citizens and Soldiers: The Dilemmas of Military Service Ithaca, NY: Cornell University Press.

Crawford, S., \& Ostrom, E. (1993). A Grammar of Institutions. American Political Science Review, 89(3), 582-600.

Damon, W. (2001). To Not Fade Away: Restoring Civil Identity Among the Youth. In D. Ravitch \& J. P. Viteritti (Eds.), Making Good Citizens: Education and Civil Society (pp. 122-141). New Haven, CT: Yale University Press.

DiMaggio, P. J., \& Powell, W. W. (1991). Introduction. In W. W. Powell \& P. J. DiMaggio (Eds.), The New Institutionalism in Organizational Analysis (pp. 1-38). Chicago: University of Chicago Press.

Ellison, C. G. (1992). Military Background, Racial Orientations, and Political Participation among Black Adult Males. Social Science Quarterly, 73(2), 360378.

Flanagan, C. A., Bowes, J. M., Jonsson, B., Csapo, B., \& Sheblanova, E. (1998). Ties that Bind: Correlates of Adolescents' Civic Commitments in Seven Countries. Journal of Social Issues, 54(3), 457-475.

Franzich, S. E. (1982). Citizens in Uniform: Political Participation among Military and Civilian Samples. Journal of Political and Military Sociology, 10(1), 15-28. 
Freeman, R. B. (1997). Working for Nothing: The Supply of Volunteer Labor. Journal of Labor Economics, 15(1), S140-S166.

Goffman, E. (1959). Asylums: Essays on the Social Situation of Mental Patients and Other Inmates Chicago: Aldine Publishing Company

Gorham, E. B. (1992). National Service, Citizenship, and Political Education. Albany: State University of New York Press.

Hayghe, H. V. (1991). Volunteers in the U.S.: Who Donates the Time? Monthly Labor Review, 17-23.

Hodgkinson, V. A., Nelson, K. E., \& Sivak, E. D. (2002). Individual Giving and Volunteering In L. M. Salamon (Ed.), The State of Nonprofit America (pp. 387420). Washington, DC Brookings Institutions Press.

Jennings, M. K., \& Markus, G. B. (1976). Political Participation and Vietnam War Veterans: A Longitudinal Study. In N. L. Goldman \& D. R. Segal (Eds.), The Social Psychology of Military Service (Vol. VI). Beverly Hills, CA: Sage Publications.

Jennings, M. K., \& Markus, G. B. (1977). The Effect of Military Service on Political Attitudes: A Panel Study. The American Political Science Review, 71(1), 131-147.

Jennings, M. K., \& Markus, G. B. (1977). The Effects of Military Service on Political Attitudes: A Panel Study. American Political Science Review, 71(1), 131-147

Lambert, M. T., \& Fowler, D. R. (1997). Suicide Risk Factors among Veterans: Risk Management in a Changing Culture of the Department of Veterans Affairs. The Journal of Mental Health Administration, 24(3), 350-358. 
Laufer, R. S., \& Gallops, M. S. (1985). Life-Course Effects of Vietnam Combat and Abusive Violence: Marital Patterns. Journal of Marriage and the Family, 47(4), $839-853$.

Laurence, J. H. (2006). Poultry and Patriotism: Attitudes toward the U.S. Military In T. W. Britt, A. B. Alder \& C. A. Castro (Eds.), Military Life: The Psychology of Serving in Peace and Combat Westport, CT: Praeger Security International

Leal, D. L. (1999). It's Not Just a Job: Military Service and Latino Political Participation. Political Behavior, 21(2), 153-174

Long, J. S. (1997). Regression Models for Categorical and Limited Dependent Variables. Thousand Oaks, CA: Sage Publications

Lovell, J. P., \& Stiehm, J. H. (1989). Military Service and Political Socialization. In R. S. Sigel (Ed.), Political Learning in Adulthood: A Sourcebook of Theory and Research (pp. 172-202). Chicago: The University of Chicago Press.

Mare, R. D., \& Winship, C. (1984). The Paradox of Lessening Racial Inequality and Joblessness among Black Youth: Enrollment, Enlistment, and Employment. American Sociological Review, 49(1), 39-55.

McPherson, J. M. (1981). A Dynamic Model of Voluntary Affiliation. Social Forces, $59(3), 705-728$.

Mettler, S. (2002). Bringing the State Back in to Civic Engagement: Policy Feedback Effects of the G.I. Bill for World War II Veterans. American Political Science Review, 96(2), 351-365.

Mettler, S. (2005). Soldiers to Citizens: The G.I. Bill and the Making of the Greatest Generation New York: Oxford University Press 
Moskos, C. C. (1982). National Service and the All-Volunteer Force. In M. Sherraden \& D. Eberly (Eds.), National Service: Social, Economic and Military Impacts (pp. 150-162). New York: Pergammon Press.

Moskos, C. C. (2000). Toward a Postmodern Military: The United States as a Paradigm In C. C. Moskos, J. A. Williams \& D. R. Segal (Eds.), The Postmodern Military: Armed Forces after the Cold War (pp. 14-31). New York: Oxford University Press.

Moskos, C. C., \& Butler, J. S. (1996). All That We Can Be: Black Leadership and Racial Integration in the Army Way. New York: Basic Books.

Musick, M., Wilson, J., \& Bynum, W. B., Jr. (2000). Race and Formal Volunteering: The Differential Effects of Class and Religion. Social Forces, 78(4), 1539-1571.

North, D. C. (1990). Institutions, Institutional Change, and Economic Performance. New York: Cambridge University Press.

Ostrom, E., Gibson, C., Shivakumar, S., \& Andersson, K. (2002). Aid, Incentives, and Sustainability. Stockholm: Swedish International Development Cooperation Agencyo. Document Number)

Pollack, J. C., White, D., \& Gold, F. (1975). When Soldiers Return: Combat and Political Alienation among White Vietnam Veterans. In D. C. Schwartz \& S. K. Schwartz (Eds.), New Directions in Political Socialization (pp. 317-333). New York: The Free Press.

President's Commission on an All-Volunteer Armed Force. (1970). The Report of The President's Commission on an All-Volunteer Armed Force Washington, DC: U.S. Government Printing Office o. Document Number) 
Putnam, R. (2000). Bowling Alone. New York: Simon and Schuster.

Rotolo, T. (1999). Trends in Voluntary Association Participation Nonprofit and Voluntary Sector Quarterly, 28(2), 199-212.

Rotolo, T., \& Wilson, J. (2006). Substitute or Complement? Spousal Influence on Volunteering. Journal of Marriage and the Family, 68, 305-319.

Schreiber, E. M. (1979). Enduring Effects of Military Service? Opinion Differences between U.S. Veterans and Nonveterans. Social Forces, 57(3), 824-839.

Shehan, C. L. (1987). Spouse Support and Vietnam Veterans' Adjustmnet to PostTraumatic Stress Disorder. Family Relations, 36(1), 55-60

Skocpol, T. (1999). Advocates without Members: The Recent Transformation of American Civic Life. In T. Skocpol \& M. P. Fiorina (Eds.), Civic Engagement in American Democracy (pp. 461-509). Washington, DC: Brookings Institution Press.

Soeters, J. L., Winslow, D. J., \& Weibull, A. (2003). Military Culture. In G. Cafonio (Ed.), Handbook on the Sociology of the Military (pp. 237-254). New York: Kluwer Academic/Plenum Publishers.

Stouffer, S. A. (1949). The American Soldier: Combat and its Aftermath (Vol. 2). Princeton, NJ: Princeton University Press.

Teigen, J. M. (2006). Enduring Effects of the Uniform: Previous Military Experience and Voting Turnout Political Research Quarterly, 59(4), 601-607.

Verba, S., Scholozman, K. L., \& Brady, H. E. (1995). Voice and Equality: Civic Voluntarism in American Politics. Cambridge, MA: Harvard University Press. 
Wakenhut, R. (1979). Effects of Military Service on the Political Socialization of Draftees. Armed Forces and Society, 626-641.

Wilson, J., \& Musick, M. (1997). Who Cares? Toward an Integrated Theory of Volunteer Work. American Sociological Review, 62(5), 694-713.

Wymer, W. W. (1997). Segmenting Volunteering Using Values, Self-Esteem, Empathy and Facilitation as Determinant Variables. Journal of Nonprofit and Voluntary Sector Marketing, 5(2), 3-28.

Xie, Y. (1992). The Socioeconomic Status of Young Male Veterans, 1964-1984. Social Science Quarterly, 73(2), 379-391.

Youniss, J., Bales, S., Christmas-Best, V., Diversi, M., McLaughlin, M., \& Silbereisen, R. (2002). Youth Civic Engagement in the 21st Century. Journal of Research on Adolescence, 12, 121-148. 


\begin{tabular}{|c|c|c|c|c|}
\hline \multicolumn{5}{|c|}{ Table 1: Characteristics of Respondents by Veteran and Volunteer Status } \\
\hline & \multicolumn{2}{|c|}{ Veteran } & \multicolumn{2}{|c|}{ Nonveteran } \\
\hline Individual Characteristics & Volunteer & Nonvolunteer & Volunteer & Nonvolunteer \\
\hline Percent male & 92 & 94 & 36 & 46 \\
\hline Mean age & 59 & 59 & 44 & 43 \\
\hline Percent white & 84 & 82 & 79 & 64 \\
\hline Percent black & 9 & 10 & 9 & 13 \\
\hline Percent Hispanic & 4 & 4 & 7 & 17 \\
\hline Percent employed & 59 & 52 & 71 & 63 \\
\hline Mean grade completed & 14.5 & 13.2 & 14.3 & 12.6 \\
\hline Percent disability & 2 & 5 & 1 & 4 \\
\hline \multicolumn{5}{|l|}{ Household Characteristics } \\
\hline Mean household income & $\$ 67,297$ & $\$ 53,767$ & $\$ 70,668$ & $\$ 52,117$ \\
\hline Mean number of household earners & 1.2 & 1.0 & 1.6 & 1.5 \\
\hline Percent married & 80 & 67 & 63 & 50 \\
\hline Mean number of children & .4 & .2 & .8 & .5 \\
\hline Percent preschool children in home & 7 & 6 & 15 & 14 \\
\hline $\begin{array}{c}\text { Mean number of household members } \\
\text { who volunteered last year / Percent } \\
\text { spouse volunteered last year }\end{array}$ & .7 & .2 & .7 & .2 \\
\hline Percent live alone & 12 & 19 & 13 & 14 \\
\hline $\begin{array}{c}\text { Mean number of household members } \\
\text { who have never volunteered }\end{array}$ & .2 & .6 & .3 & .9 \\
\hline \multicolumn{5}{|l|}{ Institutional Variables } \\
\hline Percent veteran & 10 & 10 & ---- & ----- \\
\hline Percent veterans over age 65 & 38 & 39 & $\begin{array}{ll}--- \\
\end{array}$ & $\begin{array}{ll}---- \\
\end{array}$ \\
\hline Percent veterans with disability & 2 & 5 & ---- & $\begin{array}{ll}---- \\
\end{array}$ \\
\hline Percent married veterans & 80 & 67 & $\begin{array}{c}--- \\
\end{array}$ & $\begin{array}{ll}---- \\
\end{array}$ \\
\hline Percent black veterans & 9 & 10 & $\begin{array}{c}--- \\
\end{array}$ & $\begin{array}{ll}---- \\
\end{array}$ \\
\hline Percent Hispanic veterans & 4 & 4 & $\begin{array}{cc}--- \\
\end{array}$ & $\begin{array}{ll}---- \\
\end{array}$ \\
\hline $\begin{array}{c}\text { Percent veterans who served in war } \\
\text { period }\end{array}$ & 68 & 67 & 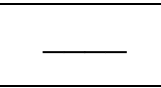 & . \\
\hline \multicolumn{5}{|l|}{ Geographical Variables } \\
\hline Percent live in metropolitan area & 80 & 80 & 82 & 84 \\
\hline Percent northeast region & 16 & 17 & 17 & 20 \\
\hline Percent Midwest region & 25 & 22 & 26 & 21 \\
\hline Percent south & 37 & 40 & 34 & 36 \\
\hline Percent west & 23 & 21 & 23 & 23 \\
\hline \multicolumn{5}{|l|}{ Other Variables } \\
\hline Percent proxy responses & 22 & 29 & 24 & 34 \\
\hline
\end{tabular}




\begin{tabular}{|c|c|c|}
\hline \multicolumn{3}{|c|}{ Table 2: Regression Results } \\
\hline & $\begin{array}{c}\text { DV = } \\
\text { Person Volunteered Last } \\
\text { Year } \\
\text { (Logit Regression) }\end{array}$ & $\begin{aligned} & \text { DV = } \text { Hours Volunteered Last } \\
& \text { Year } \\
& \\
& \text { (Tobit Regression) }\end{aligned}$ \\
\hline \multicolumn{3}{|l|}{ Individual Characteristics } \\
\hline Male & $-.541 * * *$ & $-.966 * * *$ \\
\hline Age & -.002 & $-.007 * * *$ \\
\hline White & $.489 * * *$ & $.906^{* * *}$ \\
\hline Black & $.397 * * *$ & $1.086 * * *$ \\
\hline Hispanic & $.126^{*}$ & $.535 * * *$ \\
\hline Employed & -.038 & $-.365 * * *$ \\
\hline Highest grade completed & $.130 * * *$ & $.261 * * *$ \\
\hline Disability & $-.755 * * *$ & $-1.881 * * *$ \\
\hline \multicolumn{3}{|l|}{ Household Characteristics } \\
\hline Log of household income & $.177 * * *$ & $.401 * * *$ \\
\hline Number of household earners & .013 & $.151 * * *$ \\
\hline Married & $.231 * * *$ & $.266 * * *$ \\
\hline $\begin{array}{l}\text { Number of children }<18 \text { in } \\
\text { household }\end{array}$ & $.284 * * *$ & $.553 * * *$ \\
\hline $\begin{array}{l}\text { Presence of preschoolers in } \\
\text { household }(0-5 \text { years old })\end{array}$ & $-.481 * * *$ & $-.935 * * *$ \\
\hline $\begin{array}{l}\text { Number of household members } \\
\text { that volunteered last year / Hours } \\
\text { volunteered last year by other } \\
\text { household members }\end{array}$ & $1.002 * * *$ & $.751 * * *$ \\
\hline Person lives alone & $.118^{* *}$ & $.585 * * *$ \\
\hline $\begin{array}{l}\text { Number of household members } \\
\text { that have never volunteered }\end{array}$ & $-.616 * * *$ & $-1.172 * * *$ \\
\hline \multicolumn{3}{|l|}{ Institutional Variables } \\
\hline Person is a veteran & $-.352 * * *$ & $-.972 * * *$ \\
\hline Aged $65+*$ Veteran & $.143 *$ & $.291 *$ \\
\hline Disabled*Veteran & $.482 *$ & $.943 *$ \\
\hline Married*Veteran & $.229 * *$ & $.761 * * *$ \\
\hline Black*Veteran & $.203 *$ & $.545 *$ \\
\hline Hispanic*Veteran & $.479 * *$ & $.712 *$ \\
\hline War Period & $.177 * *$ & $.398 * *$ \\
\hline \multicolumn{3}{|l|}{ Geographical Variables } \\
\hline INCMSA & $-.177 * * *$ & $.148 * *$ \\
\hline \multicolumn{3}{|l|}{ Methodological Variables } \\
\hline Proxy & $-.662 * * *$ & $-1.414 * * *$ \\
\hline $\mathrm{N}$ & 77,058 & 76,021 \\
\hline $\mathrm{R}^{2}$ & .21 & .10 \\
\hline $\mathrm{LR} \mathrm{Chi}^{2}$ & $19,518.61 * * *$ & $19,784.05^{* * *}$ \\
\hline
\end{tabular}

Note: ${ }^{\dagger} \mathrm{p}<.10,{ }^{*} \mathrm{p}<.05, * * \mathrm{p}<.01, * * * \mathrm{p}<.001$

The regression also includes three regional dummy variables, but the results for these variables are not shown. 